\title{
Disorders of Sex Development in an Infant (46, XX) - A Case Report and Review of Literature
}

\author{
Poaty $\mathrm{H}^{1,2 *}$, Ondima I ${ }^{3}$, Moyen $\mathrm{E}^{4}$, Demba Diop $\mathrm{JP}^{5}$, Moukouma $\mathrm{C}^{2}$ and Ndiaye $\mathbf{R}^{5}$ \\ ${ }^{1}$ Histology-Embryology and Genetics Laboratory, Faculty of Health Sciences, Marien Ngouabi University, Brazzaville, Congo \\ ${ }^{2}$ National Research Institute on Health Sciences, Brazzaville, Congo \\ ${ }^{3}$ Department of Chirurgy, Pediatry, $\mathrm{CHU}$ de Brazzaville, Congo \\ ${ }^{4}$ Department of Pediatrics, Neonatology, $\mathrm{CHU}$, Brazzaville, Congo \\ ${ }^{5}$ Laboratory of Cytology, Cytogenetic and Reproductive Biology, Hôspital Aristide Le Dantec, Dakar, Senegal
}

\begin{abstract}
Background: Disorders of sex development (DSD) are congenital conditions in where there is a disagreement between phenotypic sex and genotypic sex. They involve problems of management and beliefs in developing countries. We report here a ten months old Congolese infant with abnormal external genitalia and make a minireview on the normal embryonic development of genital tract and report the most common aetiologies' of DSD.
\end{abstract}

Patients and Observations: Visualization of internal genitalia was realized by genitography. Genetic sex was determined by karyotyping, fluorescent in situ hybridization (FISH) analysis and polymerase chain reaction of SRY gene.

Results: Genitographic image showed the uterus and the vaginal cavity. Karyotype and FISH visualize two $X$ chromosomes and absence of chromosome $Y$ confirmed by negative SRY PCR amplification.

Conclusion: We concluded that this infant is of ten months old is a $46, \mathrm{XX}-\mathrm{DSD}$ male external genitalia with SRY-negative.

Keywords: Disorders of sex development; Sex genes; Embryologic genital development

\section{Introduction}

A disorder of sex development (DSD) is a congenital condition where there is a disagreement between chromosomal, gonadal and phenotypic sex [1-3]. Another definition is the discordance between phenotypic sex (macroscopic or somatic) and genotypic sex (chromosome and genetic sequence) [4].

DSD are rare pathologies with an incidence estimated at 1:2,000 to 1:5,500 live births and they are due to various multifactorial etiologies [5-7]. The proposed Chicago nomenclature divides the condition in six groups (Table 1) $[7,8]$, and the terms of intersex disorders and pseudohermaphrodite are abandoned. The current etiologic classification of DSD according to the 2006 Group consensus Lawson Wilkins Paediatric Endocrine Society (LWPES)/European Society for Paediatric Endocrinology (ESPE) [8,9] depends on the adrenal or gonadal involvement and the karyotype analysis $[6,8,9]$. In congenital adrenal hyperplasia, we note that adrenal androgens excessive biosynthesis masculinizes the genitalia in $46, \mathrm{XX}[10,11]$. It is a medical

\begin{tabular}{|c|c|c|}
\hline \multirow[b]{2}{*}{ Cases } & Previous nomenclature & New nomenclature \\
\hline & Intersex & $\begin{array}{l}\text { Disorders of sex development } \\
\text { (DSD) }\end{array}$ \\
\hline 1 & Congenital adrenal hyperplasia & 46, XX DSD \\
\hline \multirow{3}{*}{2} & Male pseudohermaphrodite & \multirow{3}{*}{$46, X Y$ DSD } \\
\hline & Undervirilization of an male $X Y$ & \\
\hline & Undermasculinization of a male $X Y$ & \\
\hline \multirow{3}{*}{3} & Female pseudohermaphrodite & \multirow{3}{*}{$46, X X D S D$} \\
\hline & Overervirilization of an female $\mathrm{XX}$ & \\
\hline & Masculinazation of a female XX & \\
\hline 4 & True hermaphrodite & Ovotesticular DSD \\
\hline 5 & $X X$ male or $X X$ sex reversal & 46, XX testicular DSD \\
\hline 6 & $\mathrm{XY}$ sex reversal & $\begin{array}{c}\text { 46, XY, complete gonadal } \\
\text { dysgenesis }\end{array}$ \\
\hline
\end{tabular}

Table 1: Previous and new nomenclature in DSD individuals. emergency that must avoid a loss of $\mathrm{NaCl}$ at the risk of exposing to dehydration and to an acute renal failure. In 46, XY DSD (previously called male pseudohermaphrodite), testes are present but the external genitalia are nearly female [12]. In the group with 46, XX DSD (female pseudohermaphrodite), we note the presence of ovaries but external genitalia are incompletely male type with sometimes vaginal obliteration. In the last group, ovotesticular DSD, there is coexistence in the same gonad of both ovarian and testicular tissues [12].

The DSD are new topics in African developing countries, where diagnosis is sometimes delayed with complicated management. Their discovery even in at an early age engenders psychological disorders and problems to chose the gender of rearing [13].

In this work, we present genetic exploration of one Congolese child with abnormal external genitalia and make a review on the normal embryonic genital development and report the most common aetiologies' of DSD.

\section{Case Presentation}

A 10-months-old infant has been declared a boy with external genitalia anomalies detected by the parents. The reason for consultation was ambiguous external genitalia and no palpable testes. The infant was

*Corresponding author: Henriette Poaty, Histology-Embryology and Genetics Laboratory, Faculty of Health Sciences, Marien Ngouabi University, BP 2672, Brazzaville, Congo, Tel: (00242) 0668657 61; E-mail: henriettepoaty@gmail.com

Received October 23, 2017; Accepted November 13, 2017; Published November 18,2017

Citation: Poaty H, Ondima I, Moyen E, Demba Diop JP, Moukouma C (2017) Disorders of Sex Development in an Infant (46, XX) - A Case Report and Review of Literature. Human Genet Embryol 7: 143. doi:10.4172/2161-0436.1000143

Copyright: ( 2017 Poaty $\mathrm{H}$, et al. This is an open-access article distributed unde the terms of the Creative Commons Attribution License, which permits unrestricted use, distribution, and reproduction in any medium, provided the original author and source are credited. 
born from a normal vaginal delivery of a diamniotic and dichorionic twin pregnancy of normal development. His twin is a boy with normal development. No notion of consanguineous parents was reported.

On clinical examination, the patient does not exhibit facial dysmorphism, nor weight bearing-delay. We noted a median genital tubercle (penoclitoridal organ) with external urethral opening male type (Figure 1a), labio-scrotal (or genital) swellings evocative of labia majora and the absence of a labia minora and vaginal orifice (Figure $1 \mathrm{~b}$ ). The testes were not palpable. The anal orifice was normal. The genitographic image showed a uterine and vaginal cavity, but the fallopian tubes were not visible. The abdomino-pelvic ultrasonography was unusable. The patient was classified as Prader IV (Table 2) [12]. Hormonal investigation was not done, due to a lack of financial resources. The karyotype result was 46, XX. Fluorescent in situ hybridization analysis (FISH) (Figures 2a and 2b) was performed from lymphocyte pellets by using cytocell probes (Ref: LPF002; DXZ1 in green, DYZ3 in orange and D18Z1 in blue). It confirmed the absence of Y chromosome and the presence of two X chromosomes. The polymerase chain reaction (PCR) analysis (Figure 2c) has not detected SRY gene. From these results, the etiology of this DSD has not been defined because the patient has been

\begin{tabular}{|c|c|}
\hline Stages & Description \\
\hline I & Hypertrophic clitoris with normal others female genitalia \\
\hline II & $\begin{array}{c}\text { Hypertrophic clitoris with urogenital sinus, vaginal and urethral openings } \\
\text { covered }\end{array}$ \\
\hline III & $\begin{array}{c}\text { Hypertrophic clitoris, with posterior and complete fusion of urogenital } \\
\text { sinus, high urethro-vaginal confluence }\end{array}$ \\
\hline IV & Phallo with small urogenital opening. Detection of vaginal cavity by \\
genitography \\
\hline V
\end{tabular}

Table 2: Prader classification.
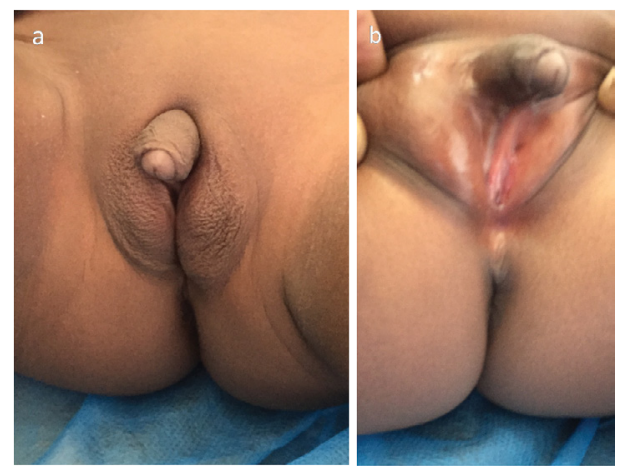

Figure 1: External genitalia anomalies. a) Penoclitoridal organ: Median penile clitoris with penile urethra and labio-scrotal folds evocative of labia majora. b) Penoclitoridal organ with labia majora but no labia minora (by complete fusion of urogenital folds) and no vaginal orifice.
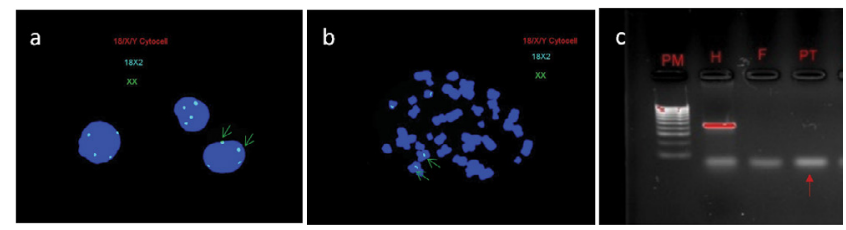

Figure 2: FISH and PCR analyses. a) FISH on cell interphasic nuclei, b) FISH on metaphasic chromosomes, showing two spots (green) of $X$ chromosome. c) Agarose gel stained with ethidium bromide showing the amplified PCR fragment of SRY gene; PM: DNA ladder (100 pb); $\mathrm{H}$ : Male control with amplification of a 486 bp SRY fragment; F: Female control with non-amplification of SRY; PT: Index patient with absence of amplification of SRY gene.

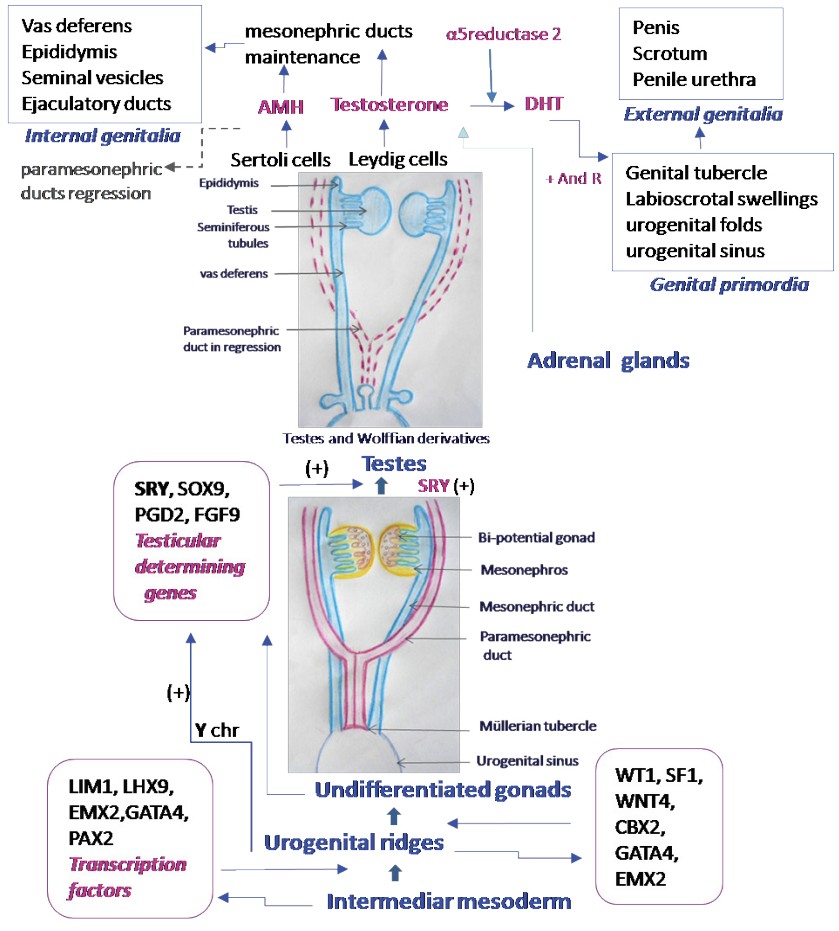

Figure 3: Embryologic genital development, genetic and hormonal factors of sexual development in male gender.

lost to view. We concluded that the infant was a 46, XX male external genitalia stage Prader IV with SRY-negative.

\section{Discussion}

It appears that a good understanding of the normal embryonic development of the human genital tract helps to understand the DSD pathogenesis and how to manage the condition. Embryologically, the genital and the urinary system have the same origin. The development of the gonads (testes and ovaries) begins around four weeks of gestation (WG) by the formation of urogenital ridges originated from a part of the third embryonic layer, the intermediate mesoderm $[8,14,15]$. From urogenital ridge cells, two cellular masses appear and evolve successively towards transitional embryonic kidneys: pronephros and mesonephros and the definitive embryonic kidneys (metanephros). Mesonephros is constituted of the mesonephric (or Wolffian) ducts and the paramesonephric (or Müllerian) ducts (Figure 3) [14,15]. At the six WG, the primordial germ cells derived from ectodermal layer migrate from yolk sac into the urogenital ridges. They join the primary sex cords (originated from mesonephros and the coelomic epithelium) in order to form the bi-potential gonads [14,15]. At this embryonic stage, the gonads are undifferentiated; they are both identical in male and female embryos (Figure 3) [14,15]. However, the embryo genetic sex is already determined during the fertilization by the presence of an $\mathrm{X}$ or $\mathrm{Y}$ chromosome coming from the paternal spermatozoa $[8,15]$.

The early gonadal differentiation is under the control of various genetic factors (Figure 4) expressed in urogenital ridges and mesonephros $[9,12,16,17]$. Approximately at the 7 WG, the specific male gene which is the transcription factor $S R Y$ (sex-determining region in the Y) mapped on Yp11.2 (with only one exon) is activated by some genes (essentially $S F-1, W T 1, C B X 2$ ) to determine the male gonadal development [15]. SRY also called TDF protein (testis-determining factor) act on primary sex cords to become testes (by developing 


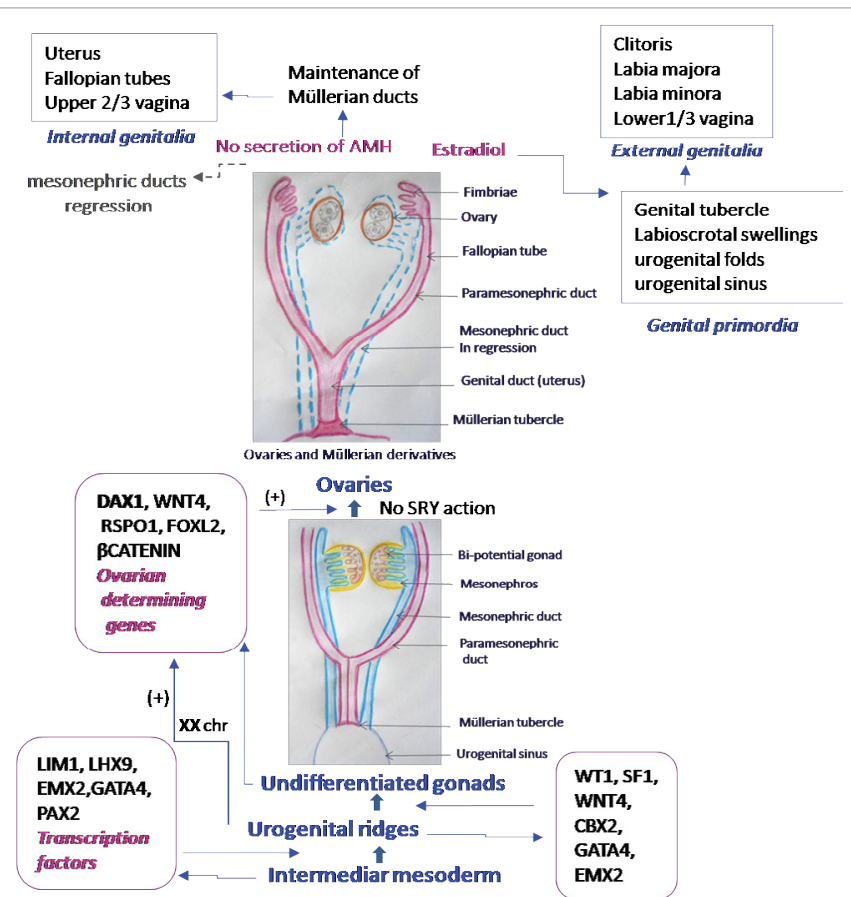

Figure 4: Embryologic genital development, genetic and hormonal factors of sexual development in female gender.

initially the seminiferous tubules) [14]. It complex with $S F-1$ (NR5A1) and transcribe other masculinizing genes such as $S O X 9, P G 2$, and FGF9 (Figure 3). Other genes which act in testis development are: ATRX, DMRT1 and DHH [9]. Afterwards, around 8WG, two male specific hormones, testosterone and anti-Müllerian hormone (AMH) involved in male sex development are secreted by two cells present in testicular cords $[10,15,17]$. Testosterone secreted by the Leydig cells lets the mesonephric ducts persist, from which arises the internal genital tract in the male: epididymis, vas deferens, seminal vesicles and ejaculatory ducts $[10,12,15]$. On the other hand, AMH secreted by Sertoli cells, induces the regression of paramesonephric ducts with the inhibition of the female internal genitalia development (Figure 3) $[14,15,18]$. Between 8-12 WG, male external genitalia (EG) and urogenital sinus are differentiated [10]. The EG development and virilisation are induced by androgens, especially dihydrotestostérone (DHT) and specific androgen receptors ( $\mathrm{A}$ and $\mathrm{R}$ ), produced by the testes and the adrenal glands. DHT results from the conversion of testosterone by $5 \alpha$-reductase type $2[10,17]$. The penis is derived from the genital tubercle (that has lengthened), the scrotum from labioscrotal swellings and penile urethra from fusion of urogenital (genital or urethral) folds $[12,14,15]$. The prostate gland originates from the urethral bud (a part of urogenital sinus) [15].

In the female gender embryo, gonadal development (ovaries) is induced on the one hand by the absence of the $\mathrm{Y}$ chromosome that prevents the expression of the SRY gene, and on the other hand by the presence of the two $\mathrm{X}$ chromosomes and the specific feminizing genes. These genes are DAX-1 (also known as NROB1) mapped on Xp21.2, RSPO1, WNT4 and FOXL2 (Figure 4) [8,9]. Primary sex cords degenerate and ovaries (containing primordial follicle with oogonia) originate from secondary sex cords $[8,15]$. The non secretion of androgens induces the regression of the mesonephric ducts at 8-9 WG, while the absence of AMH maintains the paramesonephric ducts from which the female reproductive tract is derived: the fallopian tubes, the uterus (by fusion of Müllerian ducts), and the upper two thirds of the vagina (Figure 4) $[8,12,14]$. Later, between $10-15$ WG, female external genitalia develop under the influence of androgens deficiency on the one hand, and by estrogens stimulation on the other hand. The clitoris is derived from the genital tubercle, labia majora from the labioscrotal swellings, the non-fusion of the urogenital folds forms the labia minora and the lower third of the vagina originated from urogenital sinus $[12,14,15]$.

The differentiation of the mesonephric ducts, the paramesonephric ducts and the external sexual structures allows defining the phenotypic sex. But, note that $\mathrm{Y}$ chromosome has a dominant effect, its presence (if no instability) induces male phenotype even in presence of two $\mathrm{X}$ chromosomes, except in case of mosaic (47, XXY/46, XX) in which the phenotype depends on the percentage of cells carrying SRY gene $[14,19]$.

The current knowledge on normal embryonic and fetal development as well as the new diagnosis tools allows identifying: (i) fetal phenotypic sex, by the ultrasound monitoring of the pregnancy in the first trimester (starting from $12 \mathrm{WG}$ ), period where gonads and external genitalia are already differentiated [20]. The method is efficient in $99 \%$ to $100 \%$ of cases if no anomalies [20]. (ii) However, the genetic sex may be diagnosed very early at the beginning of the embryonic segmentation stage, and in medical pratice during the first trimester of the pregnancy, for example from amniocentesis or choriocentesis.

In summary, in view of literature, normal sex development depends on three elements: the presence of specific male gene SRY on chromosome $\mathrm{Y}$, the development and differentiation of testes and ovaries (depending of gonadal determining genes and hormonal factors), and the control of phenotypic sex by the secretion of specific sex hormones and peripheral androgen and oestrogen receptors [10]. So, imbalance in one of these sex-determining factors could lead to sexual abnormal development.

For example, mutation of the $S R Y$ gene or rearrangement in the $\mathrm{Y}$ chromosome (microdeletion, isochromosome, ring chromosome) can lead to $S R Y$ gene disorders capable of inducing sexual development of the female type to 46, XY male person [21]. In contrast, translocation of SRY on chromosome X, duplication of SOX 9 or disorder in ovarian promoting genes can lead to virilisation of $46, \mathrm{XX}$ female person $[9,8,18]$. Similarly, adrenal androgens excess induces virilisation of external genitalia in female 46 , XX while internal genitalia may be intact [8].

According to the literature data, it appears that DSD in 46, XX are more reported and more frequent than in $46, \mathrm{XY}$ [8]. But, a recent large cohort study on DSDS, in South Africa reports that the predominant group found was 46, XY DSD (57.5\%), due to deficiency of androgen biosynthesis or action, while 46 , XX DSD represent $33 \%$ of patients [22]. These results are consistent with those reported in Nigeria, Italy or in Sudan studies. In the latter 32.85\% (23/70 patients) have 46, XY DSD with complete androgen insensitivity while $11.4 \%$ (8/70) patients show 46, XX DSD $[13,16,23]$.

In order to complete etiologies, we summarize the common genetic causes of DSD reported in the review in (Table 3) [3,2,24,25].

In general, to investigate the various causes of DSD needs complementary para-clinic assessment based on radiological, hormonal, genetic, genetic molecular and histological analyses [2]. Radiological analyses include endoscopy, genitography, abdominopelvic ultrasound and magnetic resonance imagery (MRI) $[4,19,20]$. 


\begin{tabular}{|c|c|c|c|c|}
\hline Diseases & Clinical manifestations & MI & $\begin{array}{l}\text { Gene / Enzyme } \\
\text { Locus/ Karyotype }\end{array}$ & References \\
\hline $\begin{array}{l}\text { Congenital adrenal } \\
\text { hyperplasia }(\mathrm{CAH})\end{array}$ & $\begin{array}{c}\text { Female IG, virilization of EG, ambiguous EG, } \\
\text { adrenal glands well visible, acute renal failure, EG } \\
\text { melanodermia }\end{array}$ & AR & $\begin{array}{c}-\mathrm{CYP} 21 \mathrm{~A} 2 / 21-\mathrm{OH}(6 \mathrm{p} 21.23)(90-95 \%) \\
-\mathrm{CYP} 11 \mathrm{~B} 1 / 11-\mathrm{OH} \\
-3 \beta H S D 2 \\
46, X X D S D\end{array}$ & {$[8,16]$} \\
\hline $\begin{array}{l}\text { Glucocorticoid receptor } \\
\text { mutations }\end{array}$ & $\begin{array}{l}\text { Ambiguous genitalia } \\
\text { Fatigue, Hypertension }\end{array}$ & $\mathrm{F}$ or $\mathrm{S}$ & - & [8] \\
\hline $\begin{array}{l}\text { Aromatase deficiency } \\
\quad \mathrm{P}^{4} 50_{\text {arom }}\end{array}$ & $\begin{array}{c}\text { Genital ambiguity, tall stature, Virilisation of mother and } \\
\text { fetus during pregnancy }\end{array}$ & & $\begin{array}{l}\text { CYP19(15p21.1) } \\
\quad 46, X X D S D\end{array}$ & [8] \\
\hline $5 \alpha-$ reductase deficiency & $\begin{array}{l}\text { Pseudovaginal perineo-scrotal hypospadias, low } \\
\text { virilisation, cryptorchidism, small penis, gynecomastia, } \\
\text { female EG }\end{array}$ & AR & $\begin{array}{c}\text { SRD5A2 / 5a-reductase type } 2 \\
(2 \mathrm{p} 23) \\
46, X Y D S D\end{array}$ & $\begin{array}{c}{[2,3]} \\
\text { ORPHA: } 753\end{array}$ \\
\hline \multicolumn{5}{|c|}{ Chromosomal anomalies } \\
\hline $\begin{array}{l}\text { Klinefelter } \\
\text { and variants }\end{array}$ & $\begin{array}{l}\text { EG and IG male phenotype, hypospadias, impuberism. } \\
\text { Gonadal dysgenesis, rare female phenotype }\end{array}$ & $\mathrm{S}$ & $\begin{array}{l}47, X X Y \text { or mosaic } \\
46, X X / 47, X X Y++\end{array}$ & {$[19,24]$} \\
\hline $\begin{array}{c}\text { Turner } \\
\text { and variants }\end{array}$ & $\begin{array}{c}\text { Female phenotype, rare male phenotype, Gonadal } \\
\text { dysgenesis, streak gonad }\end{array}$ & $\mathrm{S}$ & $\begin{array}{l}45, X 0 \text { or mosaic } \\
45, X 0 / 46, X Y++\end{array}$ & {$[21,25]$} \\
\hline \multicolumn{5}{|c|}{ Multisystem malformation syndromes } \\
\hline Denys-Drash & $\begin{array}{c}\text { Ambiguous genitalia or female EG, HTA, nephrotic } \\
\text { syndrome, Wilms'tumor, }\end{array}$ & $A D$ & $\begin{array}{l}\text { WT1 (11p13) } \\
46, X Y D S D\end{array}$ & $\begin{array}{l}\text { OMIM } \\
\# 194080\end{array}$ \\
\hline Frasier & $\begin{array}{l}\text { Ambiguous genitalia or female EG, Wilms'tumor, renal } \\
\text { failure, gonadoblastoma }\end{array}$ & $A D$ & $\begin{array}{l}\text { WT1 (11p13) } \\
46, X Y D S D\end{array}$ & $\begin{array}{c}\text { OMIM } \\
\# 136680 \\
\text { ORPHA: } 347\end{array}$ \\
\hline Fraser & $\begin{array}{l}\text { Cryptophtalmia, syndactyly, } \\
\text { laryngo-tracheal, ambiguous genitalia, clitoromegaly }\end{array}$ & AR & $\begin{array}{l}\text { FRAS1 }(4 q 21)++ \\
\text { FREM2 }(13 q 13) \\
\text { GRIP1 }(12 q 14)\end{array}$ & ORPHA: 2052 \\
\hline $\begin{array}{l}\text { Campomelic } \\
\text { dysplasia }\end{array}$ & $\begin{array}{c}\text { Gonadal dysgenesis, female appearance, skeletal } \\
\text { anomalies, dwarfism }\end{array}$ & $A D$ & $\begin{array}{c}\text { SOX9 } \\
(17 q 24.3-q 25.1) \\
46, X Y \text { sex reversal }\end{array}$ & \\
\hline $\begin{array}{l}\text { Androgen insensitivity } \\
\text { syndrome } \\
\text { (AIS) }\end{array}$ & $\begin{array}{c}\text { Gonadal dysgenesis, ambiguous genitalia, female / } \\
\text { male phenotype, ectopic testes, gynecomastia, low } \\
\text { virilisation, malignant tumors }\end{array}$ & $\begin{array}{c}\text { AR } \\
(\mathrm{X}-\text { linked })\end{array}$ & $\begin{array}{c}\text { AR gene } \\
(\mathrm{Xq11}-12) \\
46, X Y D S D\end{array}$ & {$[2,3,6]$} \\
\hline DSD in others syndromes & \multicolumn{3}{|l|}{ WAGR; Smith-Lemli-Opitz; Prader-Wili; VACTERL; CHARGE; } & {$[6,12]$} \\
\hline
\end{tabular}

Table 3: Common etiologies of the DSD.

They allow visualization of the internal genital organs. Exploratory endoscopy allows visualizing the internal genitalia better and also to realize gonadal biopsy which is important for the diagnosis of ovotesticular DSD [19].

Genetic analysis will research genotypic sex based on: cytogenetic analyses (karyotype, FISH and aCGH) to look for sex chromosomes; molecular biology (PCR MLPA, Direct sequencing] for specific sex determining genes; previously histological examination with identification of the sex chromatin (Barr body) from the buccal mucosa [16]. DNA sequencing will research for genes mutations. Hormone analysis (blood and urine) includes testicular and adrenal hormones: $\mathrm{AMH}$, testosterone, 17-hydroxyprogesterone (17-HOP), dihydrotestosterone (DHT), androstenedione (A4), dehydroepiandrosterone sulfate (DHEAS), cortisol, aldosterone; ionogram (blood and urine); gonadotrophic hormones: FSH and $\mathrm{LH}$; $5 a$-reductase type $2[1,2,7]$.

Histological analysis is essential because it allows in case of ovotesticular DSD to specify the coexistence of ovarian tissue (follicles with oogonia or oocytes) and testicular tissue (seminiferous tubes with spermatogonia or spermatozoa) [1].

The consultation of a psychologist and social care are necessary for the parents and for the patient (if he is a teenager or an adult) $[11,13]$. The announcement must be made with great delicacy, preferably in the presence of a psychologist after a complete medical check-up and if possible with an etiologic diagnosis as support. It is important to inform the patient and his parents on the condition well. Indeed, it is a heavy pathology that can cause great psychological and social problems (anxiety, shock, and decrease in the quality of life), as reported in many studies $[4,5,11,26]$. To have an appearance that is showing the doubt if someone is a man or female person, and in addition having to change macroscopic sex, is hard to bear. This is certainly the reason why our patient's mother was lost. For these reasons, giving a first name and sex declaration (like in our case) are not recommended before having complete results from the analyses.

In Congo, the condition involves problems of beliefs, diagnosis, medical and chirurgical care. But collaboration between specialists (Geneticits, anatomopathologists, endocrinologists and pediatric surgeons) is in principle a great asset in the early management of this type of pathology.

It is important to diagnose DSD at new born age or during early childhood to allow an early choice of sex, in order to initiate a medication and a feminizing or masculinizing hormone therapy at the beginning of puberty. Concerning the assignment of sex of rearing, the attribution must be rapid. The choice of sex depends, in each case, on the results of genetic analyses and on the dominant genital organ. Clinicians must inform correctly the patient about the difference between the genetic sex and the phenotypic sex. Note for example that the female sex of rearing is recommended in congenital adrenal hyperplasia 46, XX DSD and in defect in androgen action 46, XY DSD especially if Müllerian derivatives are present [7]. 


\section{Conclusion}

This case report and review of data showed that hormonal, cytogenetic and molecular biology, radiologic and histologic analyses are the best way to allow the correlation of the genotypic sex and the phenotypic sex and to propose the best rearing sex. In case of parental consanguinity (not rare in Congo), parents can also have genetic counselling after positive etiological diagnosis. Finally, an important point from this work is a challenge for us about the urgent need to have a performing genetic platform and to work in a multidisciplinary medical team in order to perform the best diagnosis and management approach in this type of pathology.

\section{Acknowledgements}

We are especially grateful to the family for the photographs and to Théophile Chomienne for the English manuscript proofreading.

\section{Conflict of Interests}

The authors declared that they have no competing interests.

\section{Author's Contributions}

IO, HP and MN established the clinical diagnosis; RN, HP, JPDD and CM performed the genetic analysis; HP drafted the paper. All the authors have read and approved the paper before submission.

\section{References}

1. Goultaiene A, Elmortaji K, Sentissi R, Moataz A, Rabii R, et al. (2016) Place de la laparoscopie dans la prise en charge des anomalies de différenciation sexuelle: à propos de 4 cas. Pan Afr Med J 23: 2-8.

2. Chan Angel OK, But WM, Lee CY, Lam YY (2015) Aetiological bases of 46, $X Y$ disorders of sex development in the Hong Kong Chinese population. Hong Kong Med J 21: 499-510.

3. Costa Mota B, Oliveira MBL, Lago R, Brito P, Campinho CAK, et al. (2015) Clinical profile of 93 cases of $46, \mathrm{XY}$ disorders of sexual development in a referral center. Int Braz J urol 41: 975-981.

4. Diakité ML, Berthé H JG, Timbely A, Diallo M, Maiga M, et al. (2013) Problématique de la prise en charge des anomalies de la différenciation sexuelle dans le service d'urologie: CHU Point G. Progress in urologie 23: 6672.

5. Selveindran MN, Syed Zakaria SZ, Jalaludin MY, Rasat R (2017) Quality of life in children with disorders of sex development. Horm Res Paediatr 88: 119-180

6. Hughes IA, Houk C, Ahmed SF, Lee PA, LWPES1/ESPE2 Consensus Group (2006) Consensus statement on management of intersex disorders. Arch Dis Child 91: 554-563.

7. Latif Ayad MA, Hamza AF (2010) Disorders of sex development. 99: 572-580.

8. Kousta E, Papathanasiou A, Skordis N (2010) Sex determination and disorders of sex development according to the revised nomenclature and classification in 46, XX individuals. Hormones 9: 218-231.
9. Öçal G (2011) Current concepts in disorders of sexual development. J Clin Res Ped Endo 3: 105-114.

10. Hiort O (2013) The differential role of androgens in early human sex development. BMC Medicine 11: 152.

11. Sandberg DE, Gardner M, Cohen-Kettenis PT (2012) Psychological aspects of the treatment of patients with disorders of sex development. Semin Reprod Med 30: 443-452.

12. Zaparackaitè I, Barauskas V (2003) Congenital genital anomalies. Aspects of diagnostics and treatment. Medicina 39: 105-113.

13. Ahmed SM, Fadl-Elmula I (2015) Clinical, cytogenetic, and molecular characterization of disorders of sexual development (DSD) in Sudan. Genomics Appl Biol 6: 1-6.

14. Encha-Razavi F, Escudier E (2008) Embrologie Humaine. De la molécule à la clinique. 4 ed. Issy-les Moulineaux: Masson 2 : 239-250.

15. Mitchell B, Sharma R (2005) Embryologie. Système génital. Elsevier, Paris pp: 1-6.

16. Laino L, Majore S, Preziosi N, Grammatico B, De Bernardo C, et al. (2014) Disorders of sex development: A genetic study of patients in a multidisciplinary clinic. Endocr Connect 3:180-192.

17. Fourati H, Frikha M, Hentati Y, Maaloul I, Ben Dhaou M, et al. (2013). Désordres de développement sexuels: 5 cas de pseudohermaphrodisme masculin. JFR pp: 1-29.

18. Jellad S, Basly M, Bougrine F, Chibani M, Rachdi R (2016) SRY- Negative 46, XX male with complete virilization and infertility: A case report. La Tunisie Médicale 94: 637.

19. Lyhyaoui O, Gaouzi A (2014) Mosaïcisme 47, XXY/46, XX et anomalie de la différenciation sexuelle : à propos d'un cas. EMHJ 20: 403-404.

20. Odeh M, Granin V, Kais M, Ophir E, Bornstein J (2009) Sonographic fetal sex determination. Obstet Gynecol Surv 64: 50-57.

21. Dos Santos AP, Ribeiro Andrade J, Santos Cruz PC (2013) Screening of $Y$ chromosome micro-deletions in 46, $X Y$ partial gonadal dysgenesis and in patients with a 45, X/46, XY karyotype or its variants. BMC Med Genet 14: 115

22. Ganie Y, Aldous C, Balakrishna Y, Wiersma R (2017) Disorders of sex development in children in KwaZulu-Natal Durban South Africa: 20-year experience in a tertiary centre. J Pediatr Endocrinol Metab 30: 11-18.

23. Ekenze SO, Nwangwu El, Amah CC (2015) Disorders of sex development in a developing country: perspectives and outcome of surgical management of 39 cases Pediatr Surg Int 31: 93.

24. Akcan N, Poyrazoğlu Ş, Baş F, Bundak R, Darendeliler F (2017) Klinefelter syndrome in childhood: Variability in clinical and molecular findings. J Clin Res Pediatr Endocrinol

25. Jacques B (1998) Dysgénésies gonadiques de phénotype féminin. Encyl Med Chir, Gynécologie 24: 7

26. Gnassingbé K, Da Silva-Anoma S, Mihleudo-Agbolan K, Anoukoum T, Bignandi K, et al. (2013) The disorders of sex development and the problems of their management in Togo. Afr J Paediatr Surg 10: 202-203. 